\title{
SKRINING SENYAWA METABOLIT SEKUNDER DAN UJI AKTIVITAS ANTIOKSIDAN EKSTRAK ETILASETAT DAUN WEDUSAN (Eupatorium odoratum)
}

\author{
Purwati, Undri Rastuti \\ Program Studi Kimia, Jurusan MIPA, Fakultas Sains dan Teknik UNSOED
}

\begin{abstract}
Oxidation process is a natural process which always occurs in fat. The process affects and decreases the fat quality. Oxidation in fat can be hampered by the addition of antioxidant. Antioxidant activity of wedusan leaf has to be studied to know the possibility of wedusan leaf as an antioxidant. Hence, the aims of the research were to determine the antioxidant activity of ethyl acetate extract of wedusan leaf using TBA method, and to compare the antioxidant activity of wedusan leaf and that of BHT. The research method consisted of sample preparation, extraction, and determination of antioxidant activity using TBA method. Wedusan leaf was extracted by maceration using n-hexane and ethyl acetate solvents. The n-hexane extract was 2.90 gram, whereas ethyl acetate extract was 13.12 gram. Based on qualitative screening on secondary metabolites, ethyl acetate extract contained flavonoid. The results from GC-MS indicated that ethyl acetate extract contained methyl heptadecanoic, methyl-13-octadecenoic, 14,16-octadecadienal, and octadecanoic acid. The order of inhibition activity of antioxidant were $0.05 \%(\mathrm{w} / \mathrm{v})$ of BHT $>0.15 \%$ $(\mathrm{w} / \mathrm{v})$ of ethyl acetate extract $>0.10 \%(\mathrm{w} / \mathrm{v})$ of ethyl acetate extract $>0.05 \%(\mathrm{w} / \mathrm{v})$ of ethyl acetate extract.
\end{abstract}

Keywords : antioxidant, TBA, BHT, Wedusan

\section{PENDAHULUAN}

Penggunaan antioksidan pada minyak telah banyak dilakukan diantaranya menggunakan antioksidan sintetik seperti Butyl Hidroksi Anisol (BHA) dan Butil Hidroksi Toluen (BHT), tetapi saat ini penggunaan antiokasidan sintetik mulai dibatasi. Hasil penelitian Ford.et al (1980) dalam Indriati (2002) menunjukkan bahwa antioksidan sintetik seperti BHT ternyata dapat meracuni binatang percobaan dan bersifat karsinogenik, sehingga akan membahayakan bagi kesehatan. Oleh karena itu, perlu dikembangkan penggunaan antioksidan alami dan mancari sumber-sumber antioksidan yang baru.

Menurut Trilaksani (2003) golongan senyawa fenolat seperti: flavonoid memiliki sifat-sifat antioksidan baik dalam lemak cair seperti minyak goreng dan dalam makanan berlemak. Senyawa tersebut dapat memberikan atom hidrogen secara cepat ke radikal lemak atau minyak yang terbentuk selama pemanasan atau mengubahkan menjadi bentuk yang lebih stabil. Sementara radikal antioksidan yang terbentuk pada reaksi tersebut lebih stabil dibandingkan dengan radikal lemak baru, dengan demikian flavonoid dapat melindungi lemak dari reaksi oksidasi.

Tanaman wedusan (Eupatorium odoratum L) merupakan tanaman yang sangat mudah tumbuh (tumbuh liar di mana-mana) dan sangat banyak, bahkan sangat tidak disukai masyarakat karena dianggap sebagai tanaman yang pengganggu yang sulit diberantas. Penelitian fitokimia terhadap daun wedusan mengandung senyawa flavonoid 
isosakuranetin dan kaemferida (Matsyeh, 1987). Dalam ekstrak etil asetat daun wedusan ditemukan senyawa flavonoid jenis flavonol, dihidroflavonol, khalkon dan flavon (Purwati, 2003). Penelitian lebih lanjut tentang metabolit sekunder yang lain untuk tanaman wedusan ini belum banyak dilakukan. Oleh karena itu, peneliti melakukan skrining senyawa metabolit sekunder dan uji aktivitas antioksidan ekstrak etilasetat daun wedusan agar mempunyai nilai lebih terutama untuk antioksidan alami, karena sampai saat ini baru digunakan sebagai pakan ternak.

\section{METODE PENELITIAN \\ Bahan dan Alat}

Bahan yang digunakan dalam penelitian ini adalah daun wedusan yang diambil di Arcawinangun, Purwokerto Timur, n-heksana, etilasetat, asam linoleat, larutan $\mathrm{FeCl}_{3} 25 \%(\mathrm{~b} / \mathrm{v}), \mathrm{HCl}$ pekat, methanol absolute, serbuk $\mathrm{Mg}$, larutan buffer fosfat $0,1 \mathrm{M} \mathrm{pH} \mathrm{7,} \mathrm{larutan}$ trikloroasetat (TCA), 20\% (b/v), larutan thiobarbiturat $0,67 \%(\mathrm{~b} / \mathrm{v})$, larutan BHT 0,05\% (b/v), dan akuades.

Peralatan penelitian antara lain : blender merk Philip, Rotary evaporator Buchi, timbangan digital, timbangan analitik, mikropipet, oven, Spektrofotometer UV-Vis Milton Roy Company Spectronic 20D, alat-alat gelas dan GC-MS QP-2010S merk SHIMADZU.

\section{Cara Kerja \\ Penyiapan sampel}

Daun wedusan dipilih yang tidak jamuran, dicuci dengan air sampai bersih, dikeringkan, kemudian diblender sampai menjadi serbuk.

\section{Maserasi}

Sebanyak 150 gram serbuk daun wedusan diekstraksi secara maserasi dengan n-heksana sampai semua serbuk terendam selama 24 jam sambil sesekali diaduk. Setelah 24 jam dilakukan penyaringan sehingga didapat filtrat dan residu. Residu dimaserasi kembali dengan n-heksana seperti perlakuan sebelumnya sampai didapat filtrat yang sudah jernih (minimal 3 kali maserasi).

Residu hasil maserasi dengan pelarut n-heksana dikeringkan dengan diangin-anginkan. Setelah kering, residu dimaserasi dengan etilasetat seperti perlakuan dengan n-heksana. Sehingga akan didapat ektrak etilasetat. Ekstrak etil asetat ini diuapkan pelarutnya dengan rotary evaporator Buchi sehingga diperoleh ekstrak etilasetat pekat. Ekstrak selanjutnya ditimbang, kemudian dilakukan skrining senyawa metabolit sekunder, uji aktivitas antioksidan dan identifikasi dengan GC-MS.

\section{Skrining senyawa metabolit sekunder (Harborne, 1987) Alkaloid (Uji Dragendorff)}

Ekstrak ditambahkan $1 \mathrm{~mL} \mathrm{HCl} 2$ $\mathrm{N}$, dipanaskan selama 5 menit, disaring, kemudian ditambahkan 5 tetes pereaksi Dragendorff. Hasil positip adanya alkaloid ditunjukkan dengan terbentuknya endapan oranye/jingga.

\section{Flavonoid (Uji Shinoda)}

Ekstrak dilarutkan dalam methanol $50 \% \quad(\mathrm{v} / \mathrm{v}), \quad$ kemudian ditambahkan serbuk $\mathrm{Mg}$ dan 4-5 tetes $\mathrm{HCl}$ pakat. Adanya senyawa flavonoid ditunjukkan dengan terbentuknya endapan merah tua/jingga.

\section{Fenol (Uji dengan $\mathrm{FeCl}_{3}$ )}

Ekstrak dilarutkan dalam akuades $10 \mathrm{~mL}$, dipanaskan selama 5 menit dan disaring. Filtrat ditambahkan 4-5 tetes pereaksi $\quad \mathrm{FeCl}_{3} \quad 2,5 \% \quad(\mathrm{~b} / \mathrm{v})$. Adanya senyawa fenol ditunjukkan dengan terbentuknya warna biru tua atau hijau hitam. 


\section{Saponin (Metode Forth)}

Ekstrak ditambahkan dalam akuades $10 \mathrm{~mL}$, kemudian dikocok selama 30 detik. Adanya senyawa saponin ditunjukkan dengan terbentuknya busa setinggi $1 \mathrm{~cm}$ dan tetap stabil selama 30 detik.

\section{Uji Aktifitas Antioksidan}

Pembuatan Larutan Uji (Boer, 2000)

Sampel yang akan diuji dibuat dengan cara menambahkan $16 \mathrm{~mL}$ buffer phosphat $0,1 \mathrm{M} \mathrm{pH} 7$ dan $20 \mathrm{~mL}$ asam linoleat $0,05 \%(\mathrm{v} / \mathrm{v})$ ke dalam $4 \mathrm{~mL}$ masing-masing ekstrak etil asetat daun wedusan $0,05 \% ; 0,10 \%$ dan $0,15 \%(\mathrm{~b} / \mathrm{v})$. Sebagai kontrol adalah asam linoleat dengan perlakuan yang sama tanpa penambahan ekstrak etil asetat daun wedusan. Kemudian sebagai pambanding terhadap sampel digunakan antioksidan BHT 0,05\% (b/v).

\section{Penentuan Panjang Gelombang Maksimum (Boer, 2000)}

Sebanyak $4 \mathrm{~mL}$ larutan uji BHT $0,05 \%$ (b/v) ditambah $2 \mathrm{~mL}$ larutan TBA $0,67 \%(\mathrm{~b} / \mathrm{v})$ dan $4 \mathrm{~mL}$ TCA $20 \%(\mathrm{~b} / \mathrm{v})$ diinkubasi dalam oven dengan suhu $60^{\circ} \mathrm{C}$ selama 24 jam. dan didinginkan selama 1 jam. Kemudian diukur absorbansinya pada panjang gelombang 450-600 nm. Panjang gelombang yang menunjukkan absorbansi tertinggi merupakan panjang gelombang maksimum dari larutan.

\section{Penentuan Waktu Setimbang (Boer, 2000)}

Sebanyak $4 \mathrm{~mL}$ larutan uji BHT $0,05 \%(\mathrm{~b} / \mathrm{v})$ ditambah $2 \mathrm{~mL}$ larutan TBA $0,67 \%$ (b/v) dan $4 \mathrm{~mL}$ TCA $20 \%$ (b/v) diinkubasi dalam oven dengan suhu $60^{\circ} \mathrm{C}$ selama 24 jam. Setelah itu larutan diukur absorbansinya pada panjang gelombang maksimum dari 10-100 menit setelah pemanasan. Pengukuran dilakukan setiap 10 menit. Waktu setimbang ditunjukkan dengan absorbansi yang paling stabil pada menit tertentu setelah pemanasan.
Pengukuran Absorbansi (Boer, 2000)

Sebanyak $4 \mathrm{~mL}$ larutan uji BHT 0,05\% (b/v) ditambah $2 \mathrm{~mL}$ larutan TBA $0,67 \%(\mathrm{~b} / \mathrm{v})$ dan $4 \mathrm{~mL}$ TCA $20 \%(\mathrm{~b} / \mathrm{v})$ diinkubasi dalam oven dengan suhu $60^{\circ} \mathrm{C}$ selama 24 jam. Kemudian didinginkan selama waktu setimbang dan diukur absorbansinya pada panjang gelombang maksimum. Pengukuran dilakukan setiap 1 hari selama 7 hari inkubasi. Perlakuan yang sama dilakukan untuk larutan uji sampel ekstrak etil asetat daun wedusan dan kontrol.

\section{Perhitungan Persentase Penghambatan Oksidasi (Faeda dkk, 2001)}

Persentase penghambatan oksidasi dihitung dengan menggunakan rumus;

$\%$ Penghambatan $=\frac{\mathrm{Ak}-\mathrm{As}}{\mathrm{Ak}} \times 100 \%$

Keterangan :

Ak : Absorbansi kontrol

As : Absorbansi sampel

\section{Identifikasi Senyawa dalam Ekstrak etilasetat dengan GC-MS}

Identifikasi senyawa dalam ekstrak etilasetat dilakukan dengan menggunakan alat GC-MS QP-2010S merk SHIMADZU di Laboratorium Kimia Organik Universitas Gadjah Mada Yogyakarta.

\section{HASIL DAN PEMBAHASAN Maserasi}

Ekstraksi daun wedusan dilakukan dengan metode maserasi tanpa pemanasan dengan tujuan senyawasenyawa target terekstrak dan tidak mengalami dekomposisi. Pelarut yang digunakan pada maserasi berturut-turut nheksana dan etil asetat. Pelarut n-heksana digunakan untuk mengekstraksi senyawasenyawa non polar yang akan mengganggu pada proses uji antioksidan, sedangkan etil asetat digunakan untuk mengekstraksi senyawa-senyawa semi 
polar yang menurut referensi senyawasenyawa fenolat seperti aglikon flavonoid sebagian besar terekstrak pada pelarut etil asetat. Hasil ekstraksi maserasi daun wedusan setelah dipekatkan dapat dilihat dalam Tabel 1.
Skrining Senyawa Metabolit Sekunder

Skrining senyawa metabolit sekunder dilakukan untuk mengetahui golongan senyawa menggunakan pereaksi warna tertentu. Skrining senyawa metabolit sekunder masingmasing ekstrak disajikan dalam Tabel 2.

Tabel 1. Hasil Maserasi

\begin{tabular}{|c|c|c|c|c|}
\hline Ekstrak & Warna & Bentuk & Berat Ekstrak (gr) & Rendemen (\%b/b) \\
\hline n-heksana & Hijau tua & Pasta & 2,9 & 1,933 \\
\hline Etilasetat & Hijau tua & Pasta & 13,12 & 8,747 \\
\hline
\end{tabular}

Tabel 2. Identifikasi senyawa metabolit sekunder dengan pereaksi warna

\begin{tabular}{|l|l|l|l|}
\hline No & \multicolumn{1}{|c|}{ Uji } & \multicolumn{1}{|c|}{ Metode Uji } & \multicolumn{1}{c|}{ Ekstrak etil asetat } \\
\hline 1. & Saponin & Forth & $(-)$ tidak terbentuk busa \\
\hline 2. & Fenol & Uji dengan $\mathrm{FeCl}_{3}$ & (+) Hijau keunguan \\
\hline 3. & Flavonoid & Shinoda & (+) ada endapan merah kecoklatan \\
\hline 4. & Alkaloid & Dragendorff & $\begin{array}{l}\text { (-) Filtrat hijau kekuningan } \\
\text { Tidak ada endapan }\end{array}$ \\
\hline
\end{tabular}

Berdasarkan hasil skrining senyawa metabolit sekunder ekstrak etil asetat dapat disimpulkan bahwa dalam ekstrak etil asetat mengandung senyawa golongan flavonoid.

\section{Uji Aktivitas Antioksidan}

Pembuatan Larutan Uji

Larutan uji disimpan dalam oven yang suhunya diatur tetap $60{ }^{\circ} \mathrm{C}$ selama 24 jam Tujuan penyimpanan larutan uji dalam oven adalah untuk mempercepat proses oksidasi lemak yaitu asam linoleat.

\begin{abstract}
Penentuan
Panjang

Gelombang

Maksimum

Penentuan panjang gelombang maksimum diperlukan untuk menetapkan serapan zat maksimum terhadap sinar pada panjang gelombang tertentu. Grafik hasil pengukuran absorbansi untuk mengetahui panjang gelombang maksimum disajikan pada Gambar 1 . Dari grafik terlihat bahwa panjang gelombang maksimum untuk larutan uji BHT diperoleh pada $520 \mathrm{~nm}$.
\end{abstract}

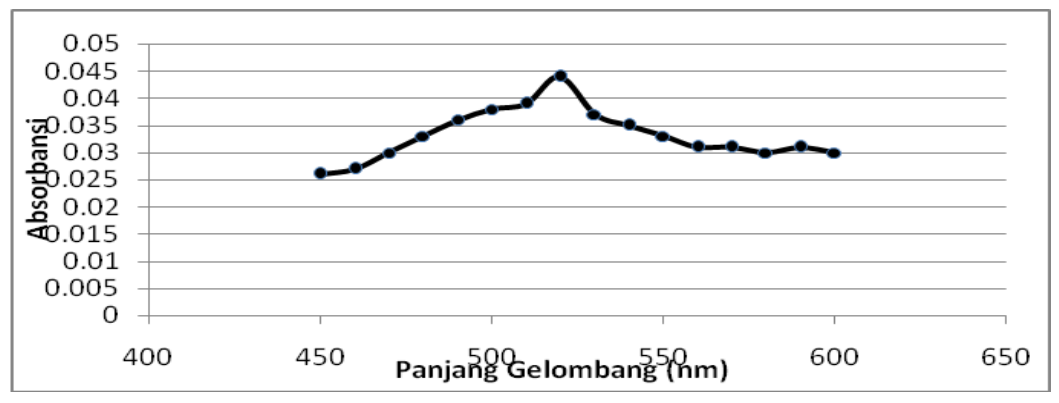

Gambar 1. Grafik Penentuan Panjang Gelombang Maksimum 


\section{Penentuan Waktu Setimbang}

Waktu setimbang reaksi ditentukan pada panjang gelombang maksimum yakni $520 \mathrm{~nm}$. Waktu Setimbang dicapai dengan melihat kestabilan absorbansi pada rentang waktu tertentu. Grafik pengamatan waktu setimbang disajikan pada Gambar 2.

Grafik penentuan waktu setimbang digunakan untuk melihat kestabilan absorbansi yang ditunjukkan dengan garis mendatar pada grafik. Waktu setimbang mengindikasikan bahwa reaksi antara pereaksi TBA dengan produk sekunder oksidasi asam linoleat telah mencapai kesetimbangan. Berdasarkan Gambar 2 kestabilan absorbansi dicapai setelah waktu 30 menit yakni pada absorbansi 0,036 .

\section{Pengukuran Aktivitas Antioksidan}

Pengukuran absorbansi dilakukan pada larutan uji yakni $4 \mathrm{~mL}$ larutan uji
BHT $0,05 \%$ (b/v), larutan ekstrak etil asetat $0,05 \%(\mathrm{~b} / \mathrm{v}), 0,10 \%(\mathrm{~b} / \mathrm{v}), 0,15 \%$ $(\mathrm{b} / \mathrm{v})$, dan control yang masing-masing ditambahkan dengan $2 \mathrm{~mL}$ TBA0,67\% (b/v) dan 4 mL TCA 20\% (b/v) kemudian dioven pada suhu $60{ }^{\circ} \mathrm{C}$.

Pengukuran aktivitas antioksidan ekstrak etil asetat dilakukan dengan metode TBA yakni mengukur absorbansi senyawa kompleks yang terbentuk dari reaksi antara TBA dengan hasil oksidasi sekunder asam linoleat pada panjang gelombang $520 \mathrm{~nm}$, setelah dibiarkan pada waktu setimbang 30 menit, Pengukuran absorbansi dilakukan 7 hari. Nilai absorbansi cenderung meningkat dari hari ke 1 hingga hari ke 7 karena semakin lama waktu penyimpanan menaikkan proses oksidasi. Data pengukuran aktivitas antioksidan dapat dilihat pada Gambar 3.

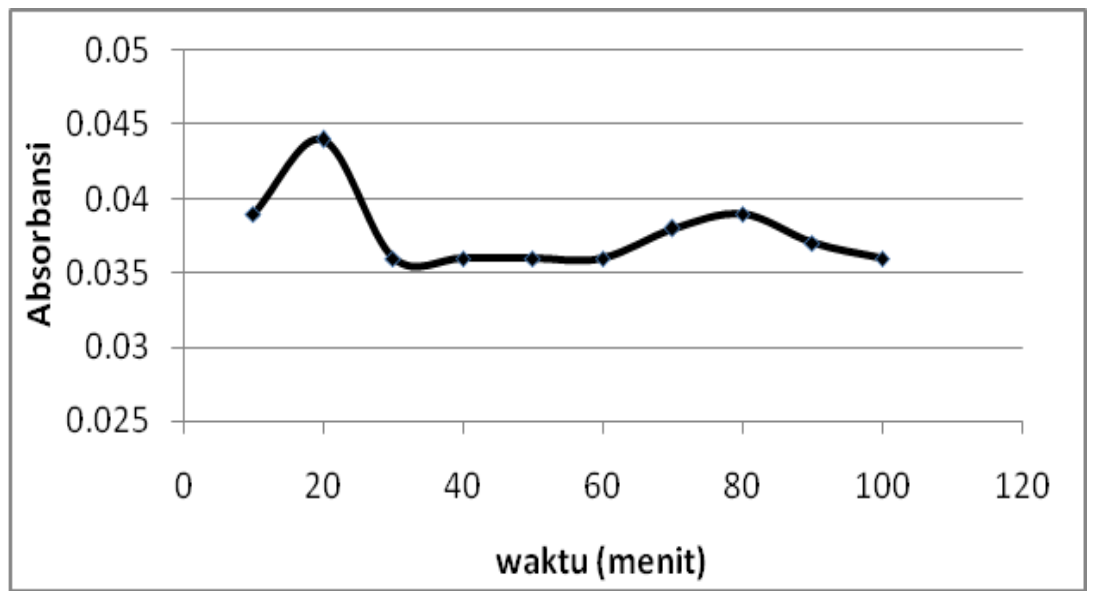

Gambar 2. Grafik penentuan waktu setimbang 


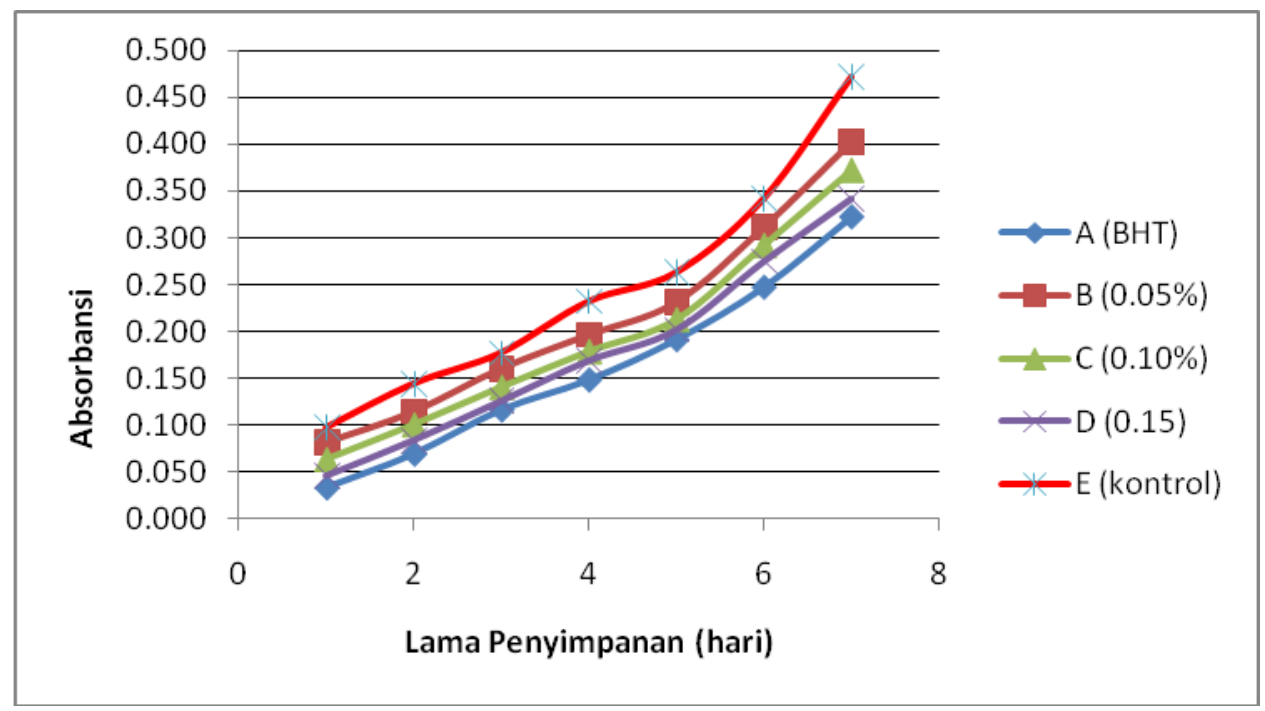

Gambar 3. Grafik pengukuran aktivitas antioksidan

Larutan uji BHT dan larutan sampel yang mengandung ekstrak etil asetat $0,05 \% \quad(\mathrm{~b} / \mathrm{v}), 0,10 \% \quad(\mathrm{~b} / \mathrm{v})$ dan $0,15 \% \quad(\mathrm{~b} / \mathrm{v})$ mengalami kenaikan konsentrasi tetapi tak setajam kontrol, ini disebabkan adanya penambahan senyawa yang bersifat antioksidan. Senyawa antioksidan ditambahkan ke dalam suatu bahan untuk menghambat reaksi oksidasi dengan udara (Scott,1963). Namun, antioksidan hanya berfungsi menghambat reaksi oksidasi dan tidak dapat menghentikan sama sekali proses autooksidasi pada lemak sehingga pada akhir proses ketengikan akan selalu terjadi. Hal ini sesuai dengan pendapat Hadiyono dkk (2002) dalam Yuliantini (2005) bahwa penambahan senyawa antiokasidan pada minyak akan menyebabkan terhambatnya pembentukan produk sekunder terutama malonaldehid. Malonaldehid ini diidentifikasikan dengan TBA menghasilkan warna merah muda. Semakin pekat warna yang dihasilkan menunjukkan semakin meningkat proses oksidasi pada asam linoleat.

Perhitungan Persentase Penghambatan Oksidasi (Faeda dkk, 2001)

Absorbansi yang diperoleh dari masing-masing larutan uji, kemudian dihitung persentase penghambatannya yakni dengan menghitung pembagian antara selisih nilai absorbansi sampel dan kontrol. Besarnya nilai penghambatan proses oksidasi dari masing-masing larutan uji dan kontrol sebagai hasil nominal dari nilai persentase penghambatan dapat dilihat pada Tabel 3.

Tabel 3 Persentase penghambatan oksidasi asam linoleat oleh BHT dan etil asetat terhadap kontrol dengan metode TBA

\begin{tabular}{|c|c|c|c|c|c|c|c|}
\hline \multirow{2}{*}{ Sampel } & \multicolumn{7}{|c|}{ Waktu inkubasi (hari) } \\
\cline { 2 - 8 } & $\mathbf{1}$ & $\mathbf{2}$ & $\mathbf{3}$ & $\mathbf{4}$ & $\mathbf{5}$ & $\mathbf{6}$ & $\mathbf{7}$ \\
\hline $\mathrm{A}$ & 65,979 & 52,083 & 34,463 & 36,207 & 27,376 & 27,778 & 31,780 \\
\hline B & 15,464 & 20,139 & 9,040 & 15,086 & 11,787 & 8,772 & 14,619 \\
\hline C & 47,143 & 29,861 & 20,339 & 22,845 & 19,011 & 14,620 & 21,186 \\
\hline D & 52,577 & 41,667 & 28,814 & 27,155 & 23,194 & 19,591 & 27,542 \\
\hline
\end{tabular}


Dari Tabel 3 terlihat bahwa persentase penghambatan sample A (BHT, sebagai kontrol positip) mempunyai persentase penghambatan terbesar, hal ini dikarenakan BHT merupakan senyawa murni sedangkan sample B, C, dan D merupakan ekstrak kasar yang mengandung banyak senyawa yang kemungkinan ada yang tidak mempunyai aktivitas sebagai antioksidan.

\section{Identifikasi Senyawa dalam Ekstrak Etil asetat dengan GC-MS}

Hasil analisa/identifikasi senyawa dalam ekstrak etil asetat dengan GC-MS dapat dilihat pada Gambar 4. Waktu retensi dan kelimpahan relatif puncak-puncak kromatogram dari ekstrak etil asetat disajikan pada Tabel 4.

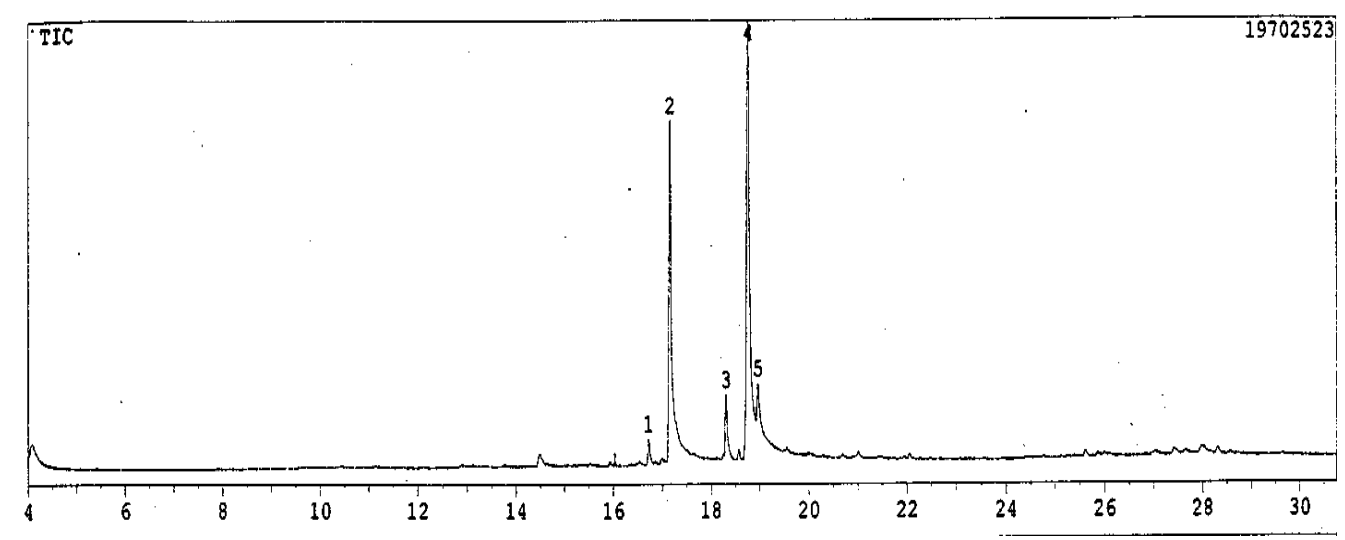

Gambar 4. Kromatogram Ekstrak Etil asetat

Tabel 4 Waktu retensi dan klimpahan relatif puncak-puncak kromatogram ekstrak etil asetat daun wedusan dengan GC-MS

\begin{tabular}{|c|c|c|}
\hline No.Puncak & Waktu retensi (menit) & Kelimpahan relatif (\%) \\
\hline 1 & 16,719 & 1,93 \\
\hline 2 & 17,171 & 33,32 \\
\hline 3 & 18,312 & 5,19 \\
\hline 4 & 18,783 & 51,33 \\
\hline 5 & 18,972 & 8,22 \\
\hline
\end{tabular}

Berdasarkan spektra massa dari tiap puncak dan setelah dibandingkan spektra standar dari literatur komputer (library), kelima puncak tersebut berturut-turut adalah metil heptadekanoat, asam heksadekanoat, 14,16-oktadekadienal dan asam oktadekanoat. Fragmentasi 2 puncak utama kromatogram ekstrak etil asetat disajikan pada Gambar 5 dan Gambar 6. 
Skrining Senyawa Metabolit ...(Purwati dan Undri Rastuti)

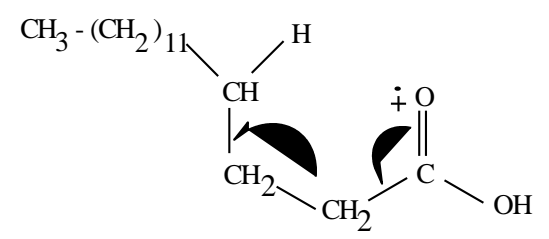

a $\mathrm{m} / \mathrm{z} 256$

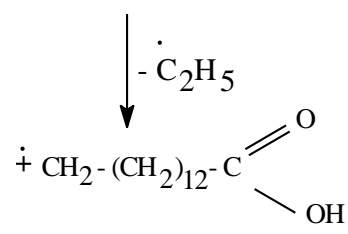

$\mathrm{b}_{2} \mathrm{~m} / \mathrm{z} 227$

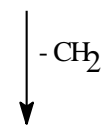

Deret $\mathrm{C}_{\mathrm{n}} \mathrm{H}_{2 \mathrm{n}-1} \mathrm{O}_{2}^{+}$

$\mathrm{m} / \mathrm{z} 213,185,171,157$,

$143,129,115,101$,

$87,73,59,45$

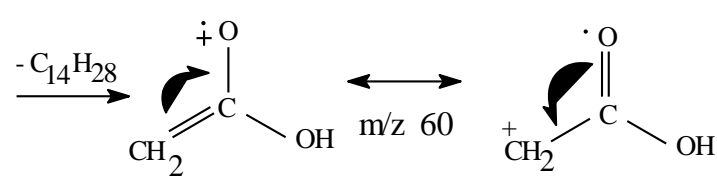

b 1

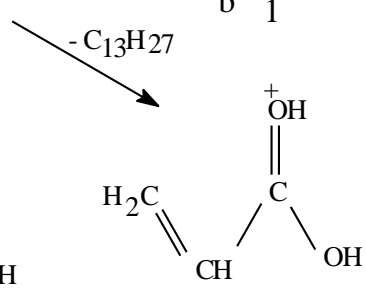

$\mathrm{b}_{3} \mathrm{~m} / \mathrm{z} 73$

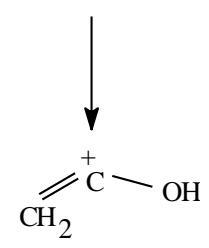

c $\mathrm{m} / \mathrm{z} 43$

Gambar 5. Mekanisme fragmentasi asam heksadekanoat yang diusulkan 
Molekul, Vol. 4. No. 2. November, 2009 : 94 - 104

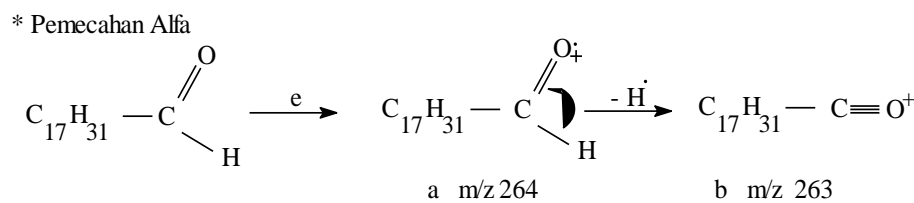

* Pemacahan Beta

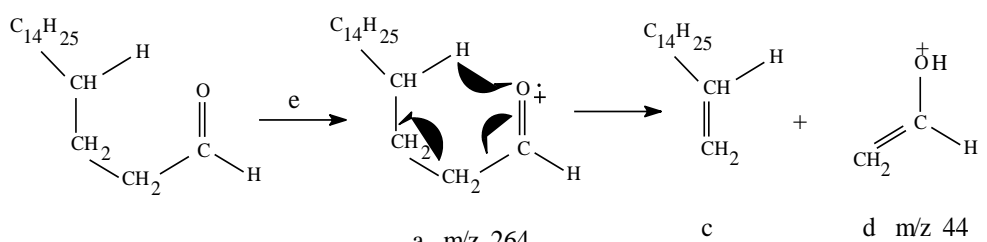

$$
\text { a } \mathrm{m} / \mathrm{z} 264 \quad \text { c } \quad \mathrm{d} \mathrm{m} / \mathrm{z} 44
$$
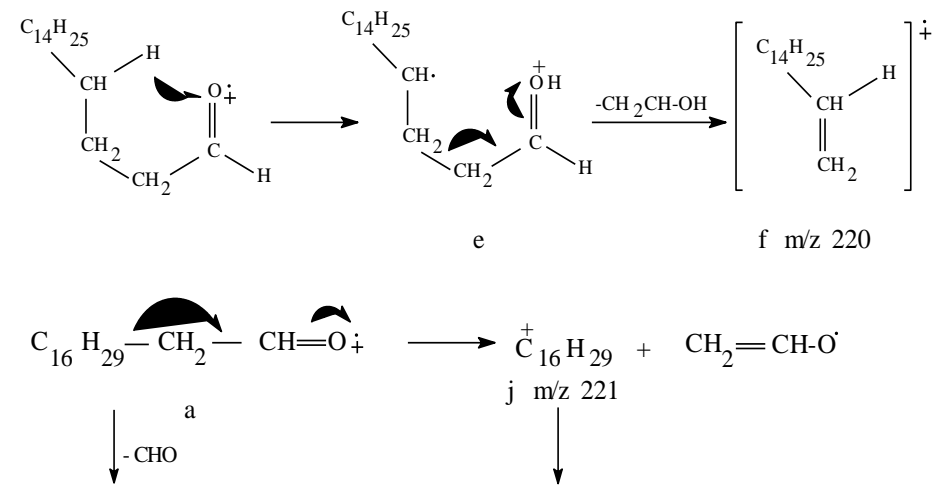

$\mathrm{C}_{16} \mathrm{H}_{29}-{ }^{-} \mathrm{CH}_{2}$

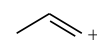

$\mathrm{m} / \mathrm{z} 235$

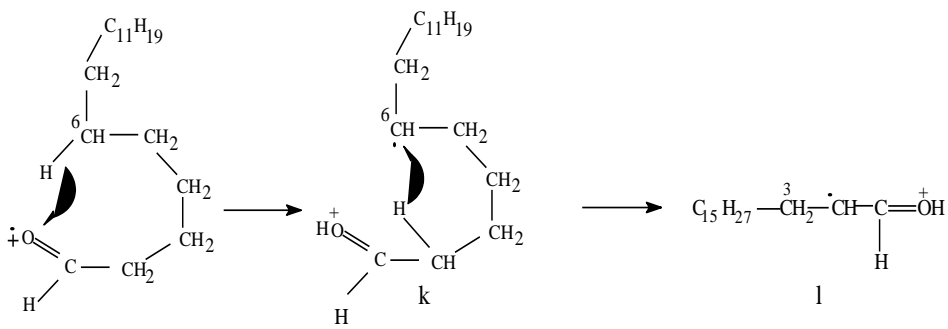

$\stackrel{3 \hat{3} 44}{\longrightarrow} \mathrm{CH}_{2}=\mathrm{CH}-\mathrm{C}=\stackrel{+}{\mathrm{O}}$

$\mathrm{m} \mathrm{m} / \mathrm{z} 57$

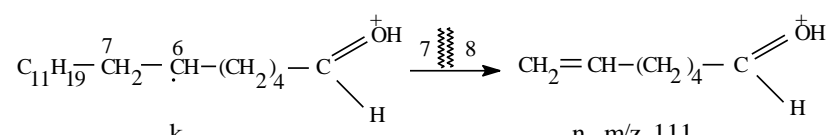

$\mathrm{n} \mathrm{m} / \mathrm{z} 111$
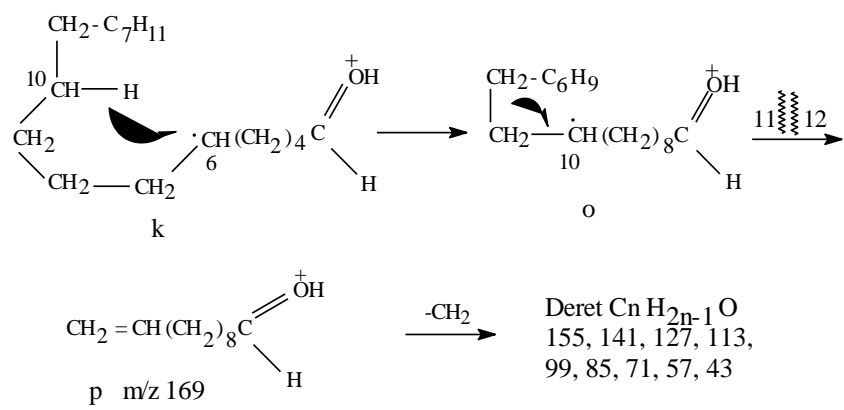

Gambar 6. Mekanisme fragmentasi 14,16-oktadekadienal yang diusulkan 


\section{KESIMPULAN DAN SARAN \\ Kesimpulan}

1. Ekstrak etil asetat daun wedusan berdasarkan skrining senyawa metabolit sekunder mengandung senyawa flavonoid, dengan GC-MS teridentifikasi adanya metil heptadekanoat, asam palmitat, metil 1,3-oktadekenoat, 14,16oktadekadienal dan asam oktadekanoat.

2. Komponen utama dalam ekstrak etil asetat daun wedusan berdasarkan GCMS adalah asam palmitat dan 14,16oktadekadienal.

3. Senyawa metabolit sekunder dalam ekstrak etil asetat daun wedusan memiliki aktivitas antioksidan dengan urutan aktivitas penghambatan sebagai berikut BHT 0,05\% (b/v) > larutan ekstrak etil asetat $0,15 \%(\mathrm{~b} / \mathrm{v})$ $>$ larutan ekstrak etil asetat $0,10 \%$ $(\mathrm{b} / \mathrm{v})>$ larutan ekstrak etil asetat $0,05 \%(\mathrm{~b} / \mathrm{v})>$ kontrol.

\section{Saran}

Perlu pemurnian lebih lanjut dengan kromatografi kolom untuk mendapatkan senyawa murni yang memiliki aktivitas antioksidan

\section{DAFTAR PUSTAKA}

Boer, Y.2000. Uji Aktivitas Antioksidan Ekstrak Kulit Buah Kandis (Garcinia parvivolia Miq). Jurnal matematika dan IPA No.1 (1) : 26-33.

Elisabeth, J. 2002. Ragam Minyak Goreng (On Line) Kompas Cyber Media, www.google.com.Diakses 15 Januari 2009

Faeda, U. A. Muhtady dan M. Mulyono. 2001. Aktivitas Antioksidan In
Vitro Ekstrak Metanol Kulit kayu Angsana. Prosiding Seminar Nasional Tumbuhan Obat Indonesia XVII. Puslitbang Kimia Terapan LIPI. Bandung

Fessenden, R.J. dan Fessenden, J.S., 1993, Organic Chemistry, third edition, Wadsworth, California (diterjemahkan oleh Pudjaatmaka, A.H., 1999, "Kimia Organik", Erlangga, Jakarta).

Harborne, J.B., Mabry, H., dan Mabry, T.J. 1975. The Flavonoid, first edition, Chapman and Hall, London.

Indriati, A .2002. Analisis Aktivitas Pada Buah Jambu Mete (On Line) Biosains, Http:// digilib. Brawijaya.ac.id/ virtual serial/pdf. Diakses 15 Januari 2005

Ketaren, S. 1988. Minyak dan Lemak Pangan, Penerbit UI, Jakarta.

Lawrence, H.M., 1958, Taxonomy of Vascular Plants. third edition, pp.438, 726-730, The Mac Millan Company, New York.

Matsjeh, S., 1987. Hasil-hasil Semulajadi dari Beberapa Obat Tradisional Melayu. disertasi. Universitas Sains Malaysia, Malaysia

Purwati. 2003. Isolasi dan Identifikasi Senyawa Organik Dalam Daun Eupatorium odoratum. Tesis.FMIPA.UGM. Yogyakarta.

Pratt dan Hudson. 1990. Flavonoids as Antiooxidants. Institute of Advanced Biomedical Tecnologies. National Council of Research. Italy 
Molekul, Vol. 4. No. 2. November, 2009 : 94 - 104

Trilaksani, W.2003. Antioksidan : Jenis, Sumber, Mekanisme, Kerja dan Peran terhadap Kesehatan (Online), www.Google.com. Diakses tanggal 15 Januari 2005

Widjaya,.2003. Peran Antioksidan Terhadap Kesehatan Tubuh. Health Choise, Edisi IV.

Winarno.,F.G. 1988. Kimia Pangan dan Gizi. Penerbit PT. Gramedia. Jakarta. 